\title{
DOI: 10.7596/taksad.v9i2.2690
}

Citation: Kerimova, R. A., \& Iskhanova, Z. S. (2020). Ethno-religious Mentality in Modern Karachay-Balkar Poetry. Journal of History Culture and Art Research, 9(2), 337-345. doi:http://dx.doi.org/10.7596/taksad.v9i2.2690

\section{Ethno-religious Mentality in Modern Karachay-Balkar Poetry}

\author{
Rauzat Abdullakhovna Kerimova ${ }^{1}$ \\ Zarema Saydyevna Iskhanova ${ }^{2}$
}

\begin{abstract}
The paper studies ethno-religious mentality issues through modern Karachay-Balkar poetry of the late XX and early XXI centuries. Global changes in the ideological, political, spiritual aspects of life have galvanized interest in determining ethnic and cultural influence on artistic creativity in modern poetry. It goes without saying that rites, customs, and other folk ethnographic elements have gradually begun disappearing; new forms are replacing them nowadays. Therefore, one of the urgent tasks in literary criticism, as we see it, is analysis of works of literature created by New-Generation Authors that reflect, in our opinion, the major trends and national peculiarities.
\end{abstract}

Literary analysis of the works of new authors are carried out for the first time. We hope we could manage to trace the specifics of the interrelationship of continuity and innovation, to research evolution nature and the prospects for the development of artistic awareness of the young poets in the region.

Keywords: Karachay-Balkar modern poetry, Ethno-religious mentality, Ethnocultural identity, Self-identity.

\footnotetext{
${ }^{1}$ Doctor of Philological Sciences, researcher of the Karachay-Balkar Literature Kabardino-Balkarian Scientific Center of the Russian Academy of Sciences, Nalchik. E-mail: k.roza07@mail.ru

2 Professor of the Department of Russian and Foreign Literature, Federal State Budgetary Educational Institution of Higher Education, Chechen State University, Chechen Republic. E-mail: 100741zir@mail.ru
} 


\section{Introduction}

The ongoing transformations in the spiritual life of the society resulted in migration of some kinds of cultural activity to the so-called national periphery.

Meanwhile, the North Caucasian literature is of a particular interest. We consider national poetry in the ethnic and cultural aspect as one of the strong symbolic trends of our study. This aspect involves moral and ethical dimensions that allow revealing recurrent patterns in the formation and evolution of national identity, cognitive structures and ethno-psychological specificity of the Karachay-Balkar Turkic ethnic group.

The researching of the issues of the ethno-national mentality within literary "reflection" is an important aspect in view of the cultural identity and ethnic markers, traditional for the KarachayBalkar ethnic group, and its poetry.

Within the framework of our investigation, it is necessary to highlight previous studies on the matter carried out by Sultanov K., Tolgurov Z. KH., Tolgurov T. Z., Maremshaova I. I., Urusbiyeva F., Bittirova T. SH., Kaziyeva A. M.,. Kuchukova Z. A., Tetuyev B. I. et al. However, despite numerous North Caucasian scholars' publications in the local literature touching upon different problems (Sultanov K., Tolgurov Z. Kh., Tolgurov T. Z., Maremshaova I., Urusbieva F., Bittirova, etc.) there are still subjects for exploration. For example changes in the ethnic awareness in the context of general universal evolutionary processes in the poetry of the last period (late XX - early XXI century).

\section{Research materials and methods}

The researches have been performed on the collection of poetry by Artur Bakkuev, Lyuba Akhmatova, Zhaukhar Lokyaeva, Aishat Kuscheterova, who joined literary processes in the late 80s; collection of the new generation's poetry by Shamil Uzdenov, Amina Gazaeva, Nauruz Bayramkulov, Diana Rakhaeva, poem collection "Teiry Kylych" (Rainbow) from young authors, and all issues of the literary magazine "Mingi tau".

For our purposes, we have applied an integrating approach with elements of comparative and historical linguistics, holistic approach, and historical-critical method. The results obtained contribute to the development of the theory of the text and discourse in view of investigating the latest Karachay and Balkar poetry.

\section{Discussion}

Considering the trends of North Caucasian literature, it can be argued that the concept of "national character" still exists in the author's state of mind. The definition encompasses search for the meaning in life and spiritual and moral values in society (Sultanov, 2001). In the poetry and other literary genres, the writers to maintain ethnic and cultural identity resisting thus the process of assimilating.

We cannot but concur the statement of N. Ponarina, that "cultural imperialism" provokes an inevitable response, expressed in a greater demand for one's own identity, preservation of the basic elements of the national picture of the world and traditional way of living" (Ponarina, 2012, p.13). 
Literary works have a crucial influence on the evolution of literature reflecting a particular era background and spiritual value. As is well known the Socialist realism was the mainstream in the art, the official style of the Soviet period. It served as one of the instruments imposed for public policy problem resolution. The Great Patriotic War of 1941 - 1945, as well as mass deportations marked a new epoch in literature, sharpening national sense of self and identity against the background of historical and social events in the USSR. From 1944 to 1957 the Karachay and Balkar peoples survived deportation. That period was tagged as "stagnant" in the Karachay-Balkar literature. The second half of the twentieth century marked the beginning of the "democratization" in the country and artistic awareness.

The situation today is characterized as contradictory. On the one hand, in all spheres of life things are changing so rapidly that society is unable to cope with them, and on the other hand, we observe cultural integration and unification. Now Russia, as well as countries throughout the world, have been facing a profound ideological crisis. Under these circumstances, new generation is assigned a key role in shaping Spiritual, Moral, Social, and Cultural values. It is the youth that "meaningfully fills" this time with particular philosophy of life and worldview. To examine and determine long-term perspectives for the national poetry development is possible only within the historical and literary context.

In this regard, Karachay-Balkar literature enters an entirely new phase, when the writers' attention is focused on the moral and ethical values of contemporaries, moral values implementation, attitude towards life, and life philosophy. The organizational focus in the artistic worldview Karachay and Balkar poets shifted to the formation of the national religious ideology and principles that guiding youngsters' equivocal behavior, and norms.

The poetry of this period is characterized by the most pressing problems, the harsh reaction to the negative phenomena of life, the exacerbation of critical pathos in relation to national historical and political concerns of the Karachay and Balkar peoples. The spiritual impoverishment and moral decay processes in the modern historical epoch are associated with the globalization pressure. In this situation, the regional artistic world cannot be left aside. The Karachay and Balkar poets like other workers of literature face the problems and are engaged in searching for the way of future development of the nation. Today, young poets inspired by the moral principle of national survival turn to the nation roots, ethnicity and ethnically marked characters, rather than to cultures global merging. In this sense, they reflect the current realities of the contemporary world very narrowly. Yet, the ongoing transformations also affect the complete picture of the artistic world they create. Sometimes there are some polemical ideas and characters that are far from the ideas and characters of the New Age in their picture.

Modern poets bold enough to forward major concerns; their concepts are mainly based on philosophical and sociological study of the reality (Mamiyeva, 2017). Social justice in the society are brought to the fore in their creative works.

Today's artists, using the power of the word, can argue more openly and honestly about different events, phenomena and life experiences. The poetry of the senior colleagues was more "muted"; we cannot but accept this fact. 
At the end of the twentieth century, questions of religious-national identity became particularly acute in national regions. The political position of the Islamic religion was strengthened, including raising this topic in the pages of lyric books written by Karachay-Balkar poets. Such tendency is attributable to the determination to confront new value orientations, which are gradually taking root in Russian society.

We should point out the 21st century Karachay-Balkar poetry is experiencing a "confusion" of poetic genres, boundaries blurring between the genres, interpenetration and mutual enrichment of one another. Each genre imposes certain conventions on the poem structure and poetry techniques; in this sense the genre inter-diffusion traditionally supplements with various types of lyrics. The "transformation" in forms is observed in the "tilek" (pray) genre.

The active inclusion of religious component we find in L. Akhmatova's "Entta bir tilek" (Another prayer), N. Bairamkulov's "Tolurm meni tilim?" ("Will my prayer come true?"), A. Gazaeva's "Hau, janym, hau ..." ("Yes, my soul, yes"), D. Rakhayeva's, "Tash kyynalalyulyrym" ("Secret experiences") (the translation from Balkar into Russian here and below carried out by the author of the paper- R. K.).

The poems tell us that outcomes of human destiny is governed by God. Enduring hardships people appeal to Allah praying for mercy and help. In addition, there has been a trend in recent years towards religious component increase in the lyric poems especially, in books devoted to the historical place, the smaller Motherland, and national issues. For example, in the poems "Allah is with us" "For the East", by Sh. Bogatyreva; "Biz taulu ell edik" (We were Balkarian villages), "Mukhazhirle orama" (Migrant Street) by M. Tabaksoev; "Zhannet zheri" (Paradise place) by D. Rakhayeva; "Jashau Dzholda "(The Road of Life) by N. Bayramkulov; "Sangyrau Kekde Joyedi ... "(Swimming in the deep sky ...) by L. Akhmatova; "Nege kerekdi ol bizge? "(Why do we need it?) I. Baituganov; " Kaytyrsa "( Come back), and "Zhaz bashi keldi ..." (Spring came ...) by A. Bakkuev (Bogatyryova, 2008; Baituganov, 2016; Bakkuev, 2007), etc. the mentioned components clearly define the theme of the poems.

The main idea of these poems is the authors' appeal to the Almighty Creator for protection, prosperity, and spiritual abundance for the nation: // Aynas, Zhulduznu Koreme, / Tabynama Allahkha: Ak-tauum yuchunleem, / Sakula anne palahdan! // (Akhmatova, 2013, p.29) (I see the moon, the star, / I worship Allah: "I die" for a snow-white mountain, / Keep it from harm). The authors are confident in employing religious language: Allah, Zhannet (Paradise), Qybla (Qibla), Duah (prayer), Iman (Faith)

We see that the system of religious beliefs the recent poets show in their books and traditional religion are similar. This phenomenon is meaningful in the Karachay-Balkar literature and has a huge impact on the ethical identity of the people as well as on the axiological system of the individual style of the young poets. Like in the works of their literary ancestors (L. Asanova and K. Mechiev) didacticcognitive aspect is a top priority; revelations are combined with emotional appeals to follow the moral rules and ethical standards of Islamic Faith (Tetuev, p. 2007).

Nation's ethical and spiritual values have been giving additional emphasis to Karachay-Balkar poetry since these years. Thus, the theme of moral values and ethical behavior guidance for ideal 
relationships in society arise in the poem of the Karachay poet A. Kuscheterova "Ata Sez" (Father's admonition):

Kartna Siyyn Köre Bilgen,

Aythanyna and Aes Bölgen,

Kyyyn Zholda da Abynamaz,

Tap, abynsa yes, zhygymaz (Kuscheterova, 2012, p.219).

The one who is able to show an old man respect

Listening to his words

Will not stumble walking a hard way

And even if he does, he will never fall.

Likewise we find the development on the same subject in a number of poetic works with the similar titles "Atamy aytyuu" (Father's proverb) by S. Uzdenov, "Atama seyu" by N. Bayramkulova, "Atam nasihaty" by D. Rakhayeva, "Ata ammanata" by A. Bakkuev. For the young poets' cohort, the tenets of morality are important and the most important among them is respecting elders. The uniqueness of the Karachays' and Balkars' ethnic psychology and the particular way of national artistic thinking are expressed using ethnographic language: adet, namys (custom / tradition, behavior norm).

In the community where culture and traditions are fading away, former moral principle that used to form the basis of the national behavior and way of life are no longer effective, it is important to heed the advice of the old men. It is the reasoning on this topic that determines the ethnical value of the above poems.

The current regional poetry at most is distinguished with concern and worry about the future of the younger generation, great desire to restore the ethical and aesthetic values, spiritual and moral foundation traits that are inherent in ancestors. Aspects of the topic of ethno-mentality, holiness of customs and traditions are associated with the issues of maintaining the native language: // Malkyar tilim, ez tilim - / Zhyuremi urgany! / Malkar tilim, shat tilim - / Zhashauumu bayraggy! // (D.Rakhaeva "Anta tilim") (Rakhaeva, 2014, p. 24) // The Balkar language is my mother tongue - / My heart! / Balkar is my language, joyful language - The banner of my life! //. The predecessors of the current Balkar and Karachay poetry regarded the Russian language as the second native one: "But there is also the Russian language. And it is forever / love and understand it like a native one. / Two speeches in my heart, like rivers, / Sound, flow and become one "(" Two Languages" by T. Zumakulova, translation by G. Efremov).

The young Balkar poet Sh. Appaev revealed his attitude to newly forming principles and behavior standards in his poem "Shendyugyu Kyzyla" (Modern Girls):

Tyutyun ichiu and Jayilip Barad

Bu Zhash Telyuni Ichinde.

Shandyugyu kyzla korlai turalla

Chashlany tyutyun ichiude (Teyri Kılıç, 2011, p.74).

More and more smoking is spreading

Among youth.

Modern girls have even surpassed boys in smoking. 
The poetic form is written as a preaching message to young girls. The author creates a highland modern female character who in a changing world has switched to modern concepts and spiritual, and moral values distinct from traditional. According to the poet, modesty and natural beauty have long been replaced by new trends coming from the West:

\author{
Turlyu-Tirlyu boyala bla \\ It was chachlaryn boyila \\ Sora, Caeslerin Ariula Sunup, \\ Xuüp, kyuzgyug karayla (Teyri Kılıç, 2011, p. 75). \\ In various colors \\ They have their hair dyed, \\ Thinking that they are beautiful, \\ They admire what they see in the mirror.
}

However, here it should be noted that the author's attention is focused intensely on the Balkar woman transformed image, not on the general highland female character. He shows his concern only within his own ethnic community. In his aversion towards the changes in the highland girl's character, the author uses harsh language accompanied with elements of satire, and unexpected comparisons: "at zhortkhan kibik" (as if riding a horse), "uyalmayla" (shamelessness), "miskinla" (unfortunate), etc.

Also the didactic religious genre emerged in the Karachay-Balkar poetry of the 21st century is clearly traced in the debutant poets' works. Their major messages aimed at realization of the greatest potential of Islamic spiritual and moral values and elimination of the western ruinous ideologies that is affecting the national self-awareness. Most of the poems of young male poets are often dedicated to the specific moral development of the Goryanka woman, her spiritual values and manners. For example this topic covers one of the poems by the Karachay poet N. Bayramkulov, "Oh, Woman!".

The ideological, religious, cultural and philosophic changes in society make the young poets put forward gender aspect for discourse. In the poetry of the masculine writers, the changes in highland girl's look and behavior are vividly described from the Androcentric viewpoint.

The feminine poets, in turn, present their vision on the transformations in young man's moral character and ethical behavior. To reveal the characters' inner world the female authors describe their manners and behavior, because it is often in actions the character demonstrates the inherent dominant traits.

We have marked new characters appeared in the 21st century female poetry. For example, in the verse by J. Appaeva "Makhtanchak" (bouncer), "Sandyrak" (chatterbox), "Makhtanchak Zhashkha" (braggart) the text is imbued with the comic spirit and irony that acquire a satirical flavor: // Badyrazhan kibik kyzarding.( blushed like a tomato) ./ Angylagan esengigi,( ok, if you understand) / Yotryuknya adamlaga (lie to people) / Bolmaida bir igiligi (no good from him) // (Teyri Kılıç, 2011, p. 41). To reinforce the author's position, J. Appaeva uses aphoristic expressions reminiscent of folk 
proverbs that convey her outlook: // ol auchilmagun auuzgja/ on a mouth that never opens / Yomurde and chibin konmaz /no mosquitoes will land // (Teyri Kılıç, 2011, p. 41).

The same character is actively developing in "Sandyrak'g'a sozyum" and (Message to the Chatterbox), and "Sandyrakny of Jyry" (The Joker's Song) by the Karachay poet Sh. Uzdenov.

The tendency to detail the objects for satirical exposure is clearly manifested in the poetry of modern Karachay-Balkar authors. The very titles of the poems often sound like denunciation. In the Sh. Uzdenov's poetry lyric is mixing with folklore episodes and satire elements. He uses these tools to expose and ridicule vices and follies of a fictional character, which often stand for real people. The young author avoid employing the grotesque and conditional forms. Instead, he holds up to gentle ridicule the absurdities and follies of human beings, aiming at producing in the reader not the anger of a Juvenal, but a wry smile.

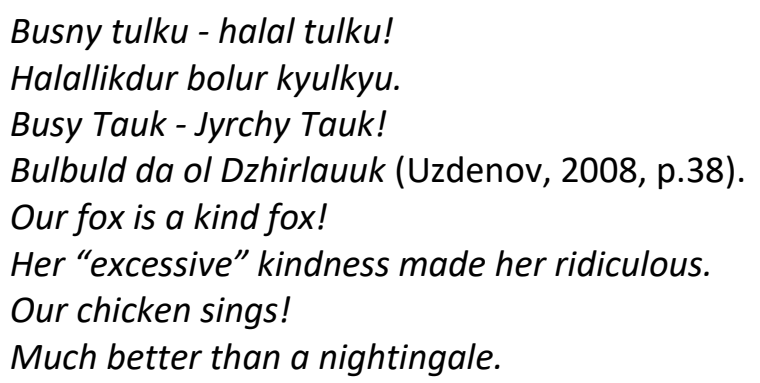

One of the most noted examples how the author achieves comedy effect is in the use of subtle and non-accusational techniques. Sh. Uzdenov is more attached to mythology, folklore, and legend: // Bir Urgüyg minib, men / Uchub Aygya Chykgyan. (I sat on the mosquito, and reached the moon. / Met a giant, / and knocked him with one blow) (Uzdenov, 2008, p. 2). The mythological and folklore characters are seen "through the lens of 'New Age'. Oral narrative poetry elements such as figurative language, stylistics, and other literary devices also make contributions: // Taudan Qarab Jugutur: Hey, Chegem El, Bir Es Boer! / Deb, Alda and Kitabna, / Ol Okudu Kyaysnny // (Uzdenov, 2008, p.17). (The mountain goat looking down from the mountain: Hey, Chegem! Look! / So he took the book, / And read the poems of Qaysyn).

The folklore and mythological forms creates a literary space where additional meanings are revealed. This helps to understand the ideological and aesthetic concept that writers conveys to their readers. Determining the significance of mythological and folklore motifs in context, establishing the peculiarities of modifications, functioning and interpretation of traditional elements /phenomena expressed in artistic form allow to penetrate the creative laboratory of the writer, to identify the governing processes and evolution in the artistic way of thinking.

\section{Results and Discussions}

The analysis and discussion given in this article put forward the investigation of key points in the development of the creative potential in the poetry of young authors. We have outlined aesthetic and semantic aspects, ethno-cultural resources and cultural value orientations. 
Development of the individual poetic creativity is considered in the context of cultural traditions, thematic specificity, and local ethnic identify, in the light of contemporary realities.

The theoretical approach have promoted determination of the particularity of the modern national poetry, and to clearly specify the objectives and directions for further study of the subject. In the newest poetic world vision, the writers' system of values is governed by national mentality and ethnical identity. Ethno-axiological approach reinforce the moral and ethical messages that lie behind the content of arising topics (home/homeland, folk traditions) (Kerimova, 2019).

Overall the analysis showed the innovative methodological model taking roots in the Russian modern literature has a positive impact on resuming of the ethnic-cultural component in the national literatures. The modern worldview and lyrical attitude contribute to updating the poetic language expanding the thematic range of art. The writer's vision is advancing at a time as he represents through characters the themes of loneliness, death, the problems that life hands us, and search for inner self. All this demonstrate combination of innovational and traditional. For young poets the socalled eternal themes continue to remain relevant today. Self-expressing through creative ideas they place their own emphasis bestowing different visions of life itself contributing to a birth of new literary themes and challenges.

Thus, I. Baituganov dedicated his poem "Halkymy zhangyryu kyunyu" (Day of Revival of my people) to the Balkar national holiday, Sh. Appaev in "Arakyi blah ushak" (A talk with alcohol) expresses his concern of psychological addiction, N. Bayramkulov in "Byugunnyu suratlary" (Portrait of modern time) touches upon the problem of the younger generation intolerance towards each other, etc.

\section{Conclusion}

It should be noted that nowadays Karachay-Balkar national literature mixes up with the history of its nation oriented on moral/ethic values. Creative efforts of the modern poets aim at maintaining national heritage and ethnic self-identity; the continuity with the past is the basic concept for the national picture of the world (Sultanov, 2001). Ethnic traditions allow the artist to be aware of his national belonging and create within the framework of cultural heritage but apart from these, he is offered the ways for further development. The author pursues a path rooted in the culture of its people and in its past traditions determining his way in literature.

Developing along with the Russian literature, Karachay-Balkar poetry, on the one hand, successively continues the legacy of previous years, and on the other hand, overcomes ideological and aesthetic constraints of the past, bringing fresh air into genre diversity, its concern "to one's own roots", history, culture, customs and traditions. Tradition and innovation, national and international coexist and interact with each other. 


\section{References}

Akhmatova, L. CH. (2013). Prayer. Poetry. Nalchik: Elbrus

Bakkuev, A. (2007). Enchantment with mountains. Poetry. Nalchik: Elbrus.

Baituganov, I. R. (2016). Steps. Poetry. Nalchik: PE Polygraphy.

Bayramkulov, N. (2012). Ships of memories. Poetry. Cherkessk.

Bogatyryova, S. (2008). Under the sign of eternity. Poetry. Cherkessk.

Gazayeva, A. H. (2015). I'm going to the bridge. Poetry. Nalchik: Elbrus.

Kerimova R. A. (2019). Ethnocultural space of modern Karachay-Balkarian poetry. Questions of literature. 2019, №4, 247-259.

Kuscheterova, A. (2012). Poetry // Mingi tau [Elbrus]. № 1 (191) January - February. Nalchik, 188-192.

Rakhaeva D. T. (2014). On the edge of fate. Poetry. Nalchik: Publishing house of M and V. Kotlyarov.

Tetuev, B. I. (2007). Karachay-Balkarian author's poetry of the second half of XIX - early XX century. Nalchik. Publishing M. and V. Kotlyarovyh.

Teyri Kılıç (Rainbow). (2011). A collection of works by young Balkarian authors: Poems, stories, tales / Comp. B.A. Glashev, M.M. Olmezas. Nalchik: Elbrus.

Vinogradov, V. V. (1961). The problem of authorship and the theory of styles. Moscow.

Sultanov, K. K. (2001). National identity and value orientation of literature. Moscow: IMLI.

Uzdenov, Sh.A. (2008). On the border. Poems. Cherkessk.

Mamiyeva, I. V. (2017). Sovremennaya osetinskaya poeziya: zhizn' posle // Izvestiya SOIGSI., № 24 (63), 133-157. DOI: 10.23671/VNC.

Readfield, R. (1955). The little community: Viewpoints for the study of a human whole. Uppsala and Stockholm.

Anderson, B. (1983). Imagined Communities; Reflections on the Origin and Spread of Nationalism. London: Verso.

Bourdieu, P. (1984). Espace social of genese des classes. Actes de la recherche on science socials. Paris, № 52-53.

Geertz, C. (1973).The Interpretation of Culture. New-York, 3-30.

Maremshaova, I. I. (2000). Basics of the ethnic consciousness of the Karachai-Balkarian people. Minsk: Technoprint. 